\title{
Controlling long-term SARS-CoV-2 infections is important for slowing
}

\section{viral evolution}

Debra Van Egeren ${ }^{1,2,3}$, Alexander Novokhodko ${ }^{4}$, Madison Stoddard ${ }^{5}$, Uyen $\operatorname{Tran}^{5}$, Diane Joseph-McCarthy ${ }^{6}$, Arijit Chakravarty ${ }^{5^{*}}$

\section{Affiliations:}

${ }^{1}$ Harvard Medical School, Boston, MA, USA.

2Dana-Farber Cancer Institute, Boston, MA, USA.

${ }^{3}$ Boston Children's Hospital, Boston, MA, USA.

${ }^{4}$ University of Washington, Seattle, WA, USA

${ }^{5}$ Fractal Therapeutics, Cambridge, MA, USA

${ }^{6}$ Boston University, Boston, MA, USA

* Corresponding author 
medRxiv preprint doi: https://doi.org/10.1101/2021.04.10.21255251; this version posted April 17, 2021. The copyright holder for this preprint

(which was not certified by peer review) is the author/funder, who has granted medRxiv a license to display the preprint in perpetuity.

It is made available under a CC-BY-ND 4.0 International license .

\section{ABSTRACT}

The rapid emergence and expansion of novel SARS-CoV-2 variants is an unpleasant surprise that threatens our ability to achieve herd immunity for COVID-19. These fitter SARSCoV-2 variants often harbor multiple point mutations, conferring one or more traits that provide an evolutionary advantage, such as increased transmissibility, immune evasion and longer infection duration. In a number of cases, variant emergence has been linked to long-term infections in individuals who were either immunocompromised or treated with convalescent plasma. In this paper, we explore the mechanism by which fitter variants of SARS-CoV-2 arise during long-term infections using a mathematical model of viral evolution and identify means by which this evolution can be slowed. While viral load and infection duration play a strong role in favoring the emergence of such variants, the overall probability of emergence and subsequent transmission from any given infection is low, suggesting that viral variant emergence and establishment is a product of random chance. To the extent that luck plays a role in favoring the emergence of novel viral variants with an evolutionary advantage, targeting these low-probability random events might allow us to tip the balance of fortune away from these advantageous variants and prevent them from being established in the population. 
medRxiv preprint doi: https://doi.org/10.1101/2021.04.10.21255251; this version posted April 17, 2021. The copyright holder for this preprint (which was not certified by peer review) is the author/funder, who has granted medRxiv a license to display the preprint in perpetuity. It is made available under a CC-BY-ND 4.0 International license .

\section{INTRODUCTION}

The widespread deployment of biomedical interventions against SARS-CoV-2 has highlighted viral evolution as a significant potential risk in bringing the ongoing pandemic to an end. SARS-CoV-2 has a high mutational rate, similar to other RNA viruses, and a high mutational tolerance in key proteins, such as Spike, the molecular target for many biomedical interventions against the disease ${ }^{1-3}$. The emergence and expansion of novel SARS-CoV-2 variants over the past few months threatens to undermine the promise of a return to normalcy as a result of the newly deployed vaccines. In fact, many of these new variants are more capable of infecting cells, spreading between hosts, and/or evading natural immunity or therapeutics ${ }^{4-6}$. On a population level, natural selection has acted to rapidly increase the frequency of these more-fit SARS-CoV2 variants, leading them to dominate the local viral population after emergence (Table S1).The emergence of fitter variants has also led in a number of cases to more severe disease outbreaks, and poses the threat of eventual reductions in vaccine efficacy ${ }^{4,5,7,8}$.

In addition to acting at the population level, natural selection has been shown to select for advantageous viral variants that are generated within individual patients infected with SARS-CoV2. Longitudinal sequencing of SARS-CoV-2 from individual patients has revealed selection for multiple antibody-evading mutations, particularly in patients with long-term infections treated with convalescent plasma ${ }^{9}$. Additionally, studies have shown that individuals with impaired immune function can shed high levels of virus for weeks, creating an environment where SARS-CoV-2 is exposed to prolonged selection pressures favoring variants that can escape the immune response and/or are resistant to treatment ${ }^{10-13}$.

Understanding the factors driving the evolutionary process for SARS-CoV-2 could potentially allow us to design and use biomedical interventions in a way that hinders viral evolution, giving us the upper hand in managing the pandemic. In particular, there are several steps in the process of generating new advantageous variants that occur largely by random chance. 
medRxiv preprint doi: https://doi.org/10.1101/2021.04.10.21255251; this version posted April 17, 2021. The copyright holder for this preprint (which was not certified by peer review) is the author/funder, who has granted medRxiv a license to display the preprint in perpetuity. It is made available under a CC-BY-ND 4.0 International license.

First, sufficient genetic diversity must be created within infected individuals through stochastic events. SARS-CoV-2 mutations are initially generated by random errors in viral replication within individuals with COVID-19. Deep sequencing studies have revealed that the SARS-CoV-2 viral population exists within the host as a quasispecies ${ }^{14,15}$, a population structure with a large number of related sequences arising from de novo mutations that occur during the course of infection ${ }^{16,17}$. Quasispecies genetic diversity has been shown to vary over time ${ }^{15,18}$, and deep sequencing studies have demonstrated a role for genetic drift $^{19}$ and intrahost transmission bottlenecks ${ }^{14}$ as the virus moves from one region of the body to another. While genetic diversity provides opportunities for advantageous mutations to arise and expand due to natural selection within individuals infected with SARS-CoV-2, genetic drift may provide a barrier to the deterministic expansion of advantageous viral mutations at lower population sizes.

Next, viral variants generated within a COVID-19 patient are transmitted to new hosts. During this process, further stochasticity is introduced by the low numbers of viral particles required to start an infection in a new host, which creates a narrow transmission bottleneck ${ }^{16,17}$. Consistent with this bottleneck, sequencing studies have provided conflicting results with respect to the ability of intrahost variants to transmit and establish new SARS-CoV-2 lineages that have the potential to transmit widely. While a number of studies have shown this to be the case ${ }^{16,17,20,21}$, other studies have not been able to demonstrate transmission of viral lineages derived from intrahost evolution ${ }^{11,22,23}$. The stochasticity in inter-host transmission of specific viral lineages is compounded by the overdispersed nature of SARS-CoV-2 spread, where most onward transmission originates from a small number of individuals. Recent work suggests an important role for stochastic extinction of variants, as at least five new infections are required in order for a newly emergent variant to establish itself in the population ${ }^{24}$.

These stochastic factors in the evolution of SARS-CoV-2 represent a potential weakness that can be exploited in the design of intervention strategies to slow viral evolution. To the extent that the stochastic contribution of drift can be increased, the deterministic contribution of natural 
medRxiv preprint doi: https://doi.org/10.1101/2021.04.10.21255251; this version posted April 17, 2021. The copyright holder for this preprint (which was not certified by peer review) is the author/funder, who has granted medRxiv a license to display the preprint in perpetuity. It is made available under a CC-BY-ND 4.0 International license .

selection to the improvement of viral fitness can be weakened. In this study, we have used evolutionary dynamics to better understand the process by which fitter SARS-CoV-2 variants arise during infections and to identify means by which viral evolution can be slowed.

\section{RESULTS}

Single mutants that are fitter within patients are more likely to be transmitted to new hosts

To investigate mutation and selection dynamics of SARS-CoV-2 within hosts, we simulated stochastic viral evolution using a modified Wright-Fisher model (Fig. 1A, Methods). During each 12-hour replication cycle, virions from the previous generation are randomly selected with probability proportional to their fitnesses to replicate and produce a burst of $N_{\mathrm{b}}$ new viral particles in the next generation. Each replicating virion has a constant probability of generating a new single point mutation that is passed to all of its $N_{b}$ progeny. The total number of virions present in each generation is given by estimates from sputum RT-PCR measurements ${ }^{25}$ (Fig. 1B, Methods). Unless stated, the parameter values for the simulations are those given in Table 1.

Over the course of a typical-length COVID-19 infection (23 days), our simulations show that viral variants with point mutations that increase the replication probability by $20-50 \%$ (selection coefficients of $0.2-0.5$ ) expand significantly more than variants with neutral or weakly deleterious fitness effects (Fig. 1C). This expansion of fitter variants increases the probability that at least one viral particle with a specific beneficial mutation will be transmitted to a new host (Fig. 1D, Methods). Individuals are more likely to pass on beneficial variants if transmission occurs later in the infection, since the frequency of these variants increases over time due to selection. Assuming these variants are also able to spread through the population with a moderate transmission advantage, new lineages with advantageous single mutations are rapidly created at the population level (Fig. 1E). These results suggest that selection for beneficial single point mutations within COVID-19 patients increases the rate at which fitter SARS-CoV-2 lineages establish at a population level. 
medRxiv preprint doi: https://doi.org/10.1101/2021.04.10.21255251; this version posted April 17, 2021. The copyright holder for this preprint (which was not certified by peer review) is the author/funder, who has granted medRxiv a license to display the preprint in perpetuity. It is made available under a CC-BY-ND 4.0 International license .

Longer infection duration and higher viral load increase probability of transmitting fitter variants

Viral load dynamics vary significantly between COVID-19 patients. To assess the evolutionary consequences of this variation, we simulated viral replication and transmission of variants for patients with different viral load kinetics (Fig. 2). Patients with longer periods of peak viral load were able to transmit fitter SARS-CoV-2 variants more efficiently (Fig. 2A). On the other hand, decreasing viral load decreased the probability that fitter variants generated within a patient would be transmitted (Fig. 2B). Both of these observations indicate that the strength of selection increases as the number of replicating viruses over the course of an infection increases.

Beneficial two-mutation combinations are readily generated within patients with long-term SARSCoV-2 infections

Many of the reported new SARS-CoV-2 variants are defined by more than one point mutation. One of these variants that arose during long-term SARS-CoV-2 infection within an immunocompromised individual included a mutation that reduced infectivity but conferred resistance to neutralizing antibodies, which was offset by a mutation that increased infectivity ${ }^{9}$. These observations suggest that highly-fit mutation combinations that require transit through a deleterious intermediate state (i.e., crossing a fitness valley) may be generated within COVID-19 patients with longer infection durations.

To investigate the rate at which these variants are generated within hosts, we modeled a multistep mutation process where beneficial mutation combinations are created from deleterious intermediates that only have some of the mutations found in the beneficial combination (Fig. 3A). Beneficial two-mutation combinations exist at very low frequencies over the timescale of a typicallength SARS-CoV-2 infection, but increase in frequency within hosts that have prolonged infections (Fig. 3B). This increase in variant frequency that occurs within hosts due to selection corresponds to an increase in the probability the beneficial two-mutation variant will be transmitted 
medRxiv preprint doi: https://doi.org/10.1101/2021.04.10.21255251; this version posted April 17, 2021. The copyright holder for this preprint (which was not certified by peer review) is the author/funder, who has granted medRxiv a license to display the preprint in perpetuity. It is made available under a CC-BY-ND 4.0 International license.

(Fig. 3C). Therefore, patients with longer SARS-CoV-2 infections are more likely to generate a variant with multiple mutations. On a population level, these individuals who produce and shed virus for long periods (> 30 days after symptom onset) increase the production rate of new variants with multiple mutations. Increasing the proportion of COVID-19 patients with prolonged SARSCoV-2 shedding increases the rate at which new, fitter variants with two mutations are produced (Fig. 3D).

SARS-CoV-2 evolution can be impeded by targeting stochastic events required for the emergence of new variants

Several steps are required for a new SARS-CoV-2 variant to be generated and established in the population (Fig. 4A), and each of these steps represents a potential choke point for viral evolution that can be exploited in the design of interventions. First, a new variant must be generated through mutation and expand within a host. The efficiency of generating and selecting advantageous variants within COVID-19 patients can be reduced by biomedical interventions that reduce viral load within patients or reduce the frequency of long-term infections which lead to viral transmission (Fig. 4B). Variants then must be transmitted to additional hosts to establish within the population. Reducing the number of viral particles transmitted to new hosts (for example, through mask wearing or vaccination) will also slow the rate of emergence of advantageous variants (Fig. 4B). Finally, interventions specifically aimed at reducing the transmissibility of the new variant would also reduce their probability of spreading widely (Fig. 4B). This could be achieved by deploying a patchwork of vaccines and other prophylactics that target distinct epitopes, deliberately increasing the diversity of biomedical interventions to provide a more challenging evasion landscape for the virus. Taken together, our simulation results suggest that there are several low-probability stochastic events that are important for SARS-CoV-2 variant emergence and that interventions targeting these events can slow SARS-CoV-2 evolution. 
medRxiv preprint doi: https://doi.org/10.1101/2021.04.10.21255251; this version posted April 17, 2021. The copyright holder for this preprint (which was not certified by peer review) is the author/funder, who has granted medRxiv a license to display the preprint in perpetuity. It is made available under a CC-BY-ND 4.0 International license.

\section{DISCUSSION}

The recent emergence of variants of SARS-CoV-2 with multiple mutations poses a direct threat to the viability of vaccine-based suppression strategies for the pandemic ${ }^{26}$. A number of phenotypic changes that are capable of providing a fitness advantage have been associated with newly emerged variants. These include increased transmissibility, lethality, and viral replication rate, all characteristics of the B.1.1.7 lineage ${ }^{5,27,28}$. Additionally, some variants have immune evading phenotypes, including increased reinfection potential (e.g., B.1.351) ${ }^{29}$, and reduced

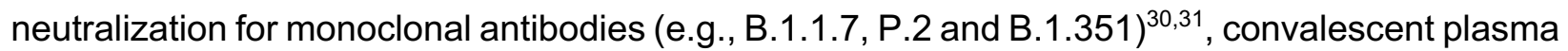
(e.g., B.1.351, B.1.429) ${ }^{29,32}$, vaccine induced sera (e.g., B.1.351, B.1.429, B.1.1.7, B1.298, P.2, and P.1) ) $^{33,34}$ or complete vaccine evasion (B.1.351) ${ }^{34}$ (see Supplemental Material for further details). Some viral variants have also been associated with a longer duration of infection ${ }^{35}$, which is particularly concerning in the light of our finding that longer infections increase the probability of transmitting fitter SARS-CoV-2 variants.

In this work, we investigated the impact of within-host SARS-CoV-2 mutation and selection on the emergence of new viral variants in the population. Using a stochastic computational model of viral replication and selection, we found that mutations that increased the rate of viral replication increased in frequency within hosts during the course of a typical SARS-CoV-2 infection. This expansion led to more frequent transmission of the new variant and faster emergence of the variant on a population level. The effect of selection within hosts is more pronounced for longer SARS-CoV-2 infections with higher viral load, which can lead to the generation of variants with multiple mutations within a single host during prolonged infection. Thus, our work provides a quantitative understanding of the evolutionary mechanisms by which prolonged SARS-CoV-2 infections lead to the emergence of fitter viral variants.

This work, along with other recent findings on the stochastic nature of SARS-CoV-2 transmission ${ }^{24}$, suggests strategies that can be used to suppress the emergence of these fitter viral variants, thereby slowing the evolution of SARS-CoV-2. First, long-term SARS-CoV-2 
medRxiv preprint doi: https://doi.org/10.1101/2021.04.10.21255251; this version posted April 17, 2021. The copyright holder for this preprint (which was not certified by peer review) is the author/funder, who has granted medRxiv a license to display the preprint in perpetuity. It is made available under a CC-BY-ND 4.0 International license.

infections (lasting longer than 30 days) should be treated as a serious public health concern, regardless of the presence of symptoms. Our work suggests that the low frequency of such longterm cases belies the threat that they pose to public health. In particular, asymptomatic long-term infections still transmit ${ }^{10-13}$ and can potentially be efficient accelerators of viral evolution. Isolation measures for such long-term infections should be designed to minimize transmission in the interest of minimizing their disproportionate impact on the pace of viral evolution. This would represent a departure from current practice (the CDC, for example, does not require negative testing prior to ending isolation for mild and asymptomatic casis of COVID-19 ${ }^{36}$ ). Second, treatments for long-term viral infections should be aimed at the suppression of viral load and should be initiated regardless of whether patients are symptomatic. Such treatment regimes should consist of at least three active agents that can suppress viral replication and preferably target viral proteins other than Spike to reduce the risk of generating viral mutants that are resistant to the treatment. This shift in medical practice may reduce the risk of intrahost evolution leading to emergence of immune-evading SARS-CoV-2 variants, as likely occurred in some documented cases with convalescent plasma treatment ${ }^{9}$. Finally, contact tracing of transmission events and genetic characterization of secondary infections resulting from long-term infections (or from immunosuppressed patients) will be crucial.

We note that detecting long-term infections with SARS-CoV-2 represents a major logistical challenge in its own right- a widely deployable method for distinguishing long-term infections from spurious PCR results is an unmet need at present. While viral culture can be used to confirm the presence of replication-competent virus ${ }^{37}$, logistical constraints (such as turnaround time and the requirement for Biosafety Level 3 containment) limit its clinical use ${ }^{38}$. Subgenomic RNA (sgRNA) has been proposed as a biomarker for actively replicating virus ${ }^{39}$, but this remains controversial at present ${ }^{40}$. Therefore, there is an urgent need to develop a validated biomarker for viral replication in long-term infections. 
medRxiv preprint doi: https://doi.org/10.1101/2021.04.10.21255251; this version posted April 17, 2021. The copyright holder for this preprint (which was not certified by peer review) is the author/funder, who has granted medRxiv a license to display the preprint in perpetuity. It is made available under a CC-BY-ND 4.0 International license .

Our work also suggests reasons for concern if intrahost evolution in long-term SARS-CoV2 infections is not addressed directly. As intrahost evolution leads to faster generation of beneficial variants at a population level, new waves of transmission driven by fitter viral variants can be expected to arise as a result of untreated long-term infections. Our results also suggest another evolutionary incentive favoring increased infection duration, since long-term SARS-CoV-2 infections increase the rate at which the virus evolves. To the extent that this evolution is shaped by immune evasion, this study also points out an evolutionary route that is open to SARS-CoV-2, by which the virus can evolve to become progressively more lethal. Notably, while this potential risk conflicts with recent work that has conjectured that SARS-CoV-2 evolution may lead to progressive decreases in viral virulence ${ }^{41}$, it is consistent with available real-world evidence for this virus so $\operatorname{far}^{27}$. The evolution of increased virulence over time has been observed for several other viral pandemics, including for HIV over the years $1984-2010^{42}$, the second wave of the 19181919 Influenza pandemic ${ }^{43}$, and myxomatosis in rabbits in the 1970 s and $80 s^{44-46}$.

The deployment of multiple vaccines against SARS-CoV-2 in under a year is a remarkable triumph of modern medicine. These vaccines hold the promise of bringing the current pandemic to an end, but are vulnerable to the rapid emergence and expansion of immune-evading viral variants. Understanding the mechanism of SARS-CoV-2 evolution allows us to design strategies that can tip the balance in this evolutionary arms race and ultimately allow us to control the spread of SARS-CoV-2.

\section{METHODS}

\section{Intrahost viral dynamics simulations}

We used a modified Wright-Fisher evolutionary model to investigate viral mutation and selection dynamics within individuals with COVID-19. This model assumes that SARS-CoV-2 virions replicate in discrete generations of length $t_{\mathrm{g}}$ and that each replicating virion produces a fixed burst size of new virions $N_{\mathrm{b}}$. The total number of virions present at each generation was 
medRxiv preprint doi: https://doi.org/10.1101/2021.04.10.21255251; this version posted April 17, 2021. The copyright holder for this preprint (which was not certified by peer review) is the author/funder, who has granted medRxiv a license to display the preprint in perpetuity. It is made available under a CC-BY-ND 4.0 International license .

estimated from nasopharyngeal swab and sputum qRT-PCR measurements after diagnosis ${ }^{25}$. During each replication cycle, $N_{t} / N_{b}$ virions from the previous generation are chosen to reproduce, where $N_{\mathrm{t}}$ is the total number of virions in the current generation and $N_{\mathrm{b}}$ is the burst size. Each virion from the previous generation has a probability of reproducing and contributing $N_{\mathrm{b}}$ virions to the next generation that is proportional to its fitness. During each replication, there is a constant probability of generating a particular mutation that will be present in all $N_{\mathrm{b}}$ virions that are produced by that parent virion. Parameter values used for simulations are given in Table 1.

\section{Probability of variant transmission from a single infected host}

The probability that a transmission event that occurs within a particular time window during infection was estimated by assuming new infections are initiated by $N_{\text {trans }}$ virions sampled uniformly at random from the transmission period which go on to establish a new infection. Therefore, the probability that at least one virion with a specific mutation is passed on is $1-(1-$

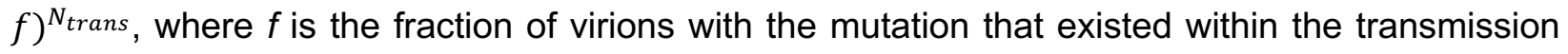
window.

Population-level de novo generation rate of SARS-CoV-2 variants

A newly-generated variant present in a single patient will initially spread stochastically to new hosts, the success of which will determine whether the variant will survive in the population. We modeled this stochastic spread as a branching process in which infected individuals infect on average $R_{0}$ new hosts. More specifically, each infected individual transmits to $X$ new hosts, where $X$ is a random variable distributed as Poisson $\left(R_{0}\right)$. Probability theory results for Poisson branching processes states that if a new variant has $R_{0}>1$, it will survive with probability $\pi$, where $\pi$ is the smallest solution to $\pi=1-e^{-R_{0} \pi}$ in the interval $[0,1]^{47}$.

The rate at which new surviving variants are generated from patients with infections of length $i$ is $\pi \sigma_{i} p_{i}$, where $p_{i}$ is the probability of a patient with infection length $i$ generating and 
medRxiv preprint doi: https://doi.org/10.1101/2021.04.10.21255251; this version posted April 17, 2021. The copyright holder for this preprint (which was not certified by peer review) is the author/funder, who has granted medRxiv a license to display the preprint in perpetuity. It is made available under a CC-BY-ND 4.0 International license .

transmitting the variant and $\sigma_{i}$ is the number of patients with infection length $i$ that are infected each day. The total rate at which new surviving variants are generated in the population is just the sum over all infection lengths, $\sum_{i} \pi \sigma_{i} p_{i}$. To estimate $\sigma_{i}$, we assumed that most infections were of the typical length and viral load kinetics shown in Fig. 1B. However, a small fraction $p_{\mathrm{LT}}$ of infections were assumed to be longer than 30 days. The distribution of infection lengths in these long-term patients was assumed to be normal, and mean and standard deviation were estimated from longitudinal oral swab RT-PCR data ${ }^{48}$. The rate $z_{L T}$ at which new surviving variants are generated from long-term patients was estimated by simulating infections that are 1, 2, 3, 4, 5, 10 , or 15 weeks longer than typical infections to estimate $p_{i}$ for each infection length and multiplying by the fraction of long-term infections within the length interval ending at $i$. That is, $z_{L T}=\sum_{i} \pi \sigma_{i} p_{i}$ for $i$ in $\{30,37,44,51,58,95,128\}$ days, where $\sigma_{i}=\mathrm{P}(X<i)-\sigma_{i-1}$ and $X$ is normally distributed according to the distribution of infection lengths. The total rate at which new surviving variants are generated in the entire population is therefore $z_{\mathrm{LT}}+z_{\mathrm{ST}}$, where $z_{\mathrm{ST}}$ is the rate at which standard length infections produce the variant.

\section{REFERENCES}

1. Starr, T. N. et al. Deep Mutational Scanning of SARS-CoV-2 Receptor Binding Domain Reveals Constraints on Folding and ACE2 Binding. Cell 182, 1295-1310 (2020).

2. Baum, A. et al. Antibody cocktail to SARS-CoV-2 spike protein prevents rapid mutational escape seen with individual antibodies. Science 369, 1014-1018 (2020).

3. Van Egeren, D. et al. Risk of evolutionary escape from neutralizing antibodies targeting SARS-CoV-2 spike protein. medRxiv 2020.11.17.20233726 (2020) doi:10.1101/2020.11.17.20233726.

4. Abdool Karim, S. S. \& de Oliveira, T. New SARS-CoV-2 Variants - Clinical, Public Health, and Vaccine Implications. New England Journal of Medicine 0, null (2021). 
medRxiv preprint doi: https://doi.org/10.1101/2021.04.10.21255251; this version posted April 17, 2021. The copyright holder for this preprint

(which was not certified by peer review) is the author/funder, who has granted medRxiv a license to display the preprint in perpetuity.

It is made available under a CC-BY-ND 4.0 International license .

5. Davies, N. G. et al. Estimated transmissibility and impact of SARS-CoV-2 lineage B.1.1.7 in England. Science (2021) doi:10.1126/science.abg3055.

6. Tada, T. et al. Decreased neutralization of SARS-CoV-2 global variants by therapeutic antispike protein monoclonal antibodies. bioRxiv 2021.02.18.431897 (2021) doi:10.1101/2021.02.18.431897.

7. Tegally, H. et al. Emergence and rapid spread of a new severe acute respiratory syndromerelated coronavirus 2 (SARS-CoV-2) lineage with multiple spike mutations in South Africa. medRxiv 2020.12.21.20248640 (2020) doi:10.1101/2020.12.21.20248640.

8. Sabino, E. C. et al. Resurgence of COVID-19 in Manaus, Brazil, despite high seroprevalence. The Lancet 397, 452-455 (2021).

9. Kemp, S. A. et al. SARS-CoV-2 evolution during treatment of chronic infection. Nature 1-10 (2021) doi:10.1038/s41586-021-03291-y.

10. Choi, B. et al. Persistence and Evolution of SARS-CoV-2 in an Immunocompromised Host. New England Journal of Medicine 383, 2291-2293 (2020).

11. Valesano, A. L. et al. Temporal dynamics of SARS-CoV-2 mutation accumulation within and across infected hosts. bioRxiv 2021.01.19.427330 (2021) doi:10.1101/2021.01.19.427330.

12. Baang, J. H. et al. Prolonged Severe Acute Respiratory Syndrome Coronavirus 2 Replication in an Immunocompromised Patient. J Infect Dis 223, 23-27 (2021).

13. Truong, T. T. et al. Persistent SARS-CoV-2 infection and increasing viral variants in children and young adults with impaired humoral immunity. medRxiv 2021.02.27.21252099 (2021) doi:10.1101/2021.02.27.21252099.

14. Rueca, M. et al. Compartmentalized Replication of SARS-Cov-2 in Upper vs. Lower Respiratory Tract Assessed by Whole Genome Quasispecies Analysis. Microorganisms 8, (2020).

15. Ramazzotti, D. et al. VERSO: A comprehensive framework for the inference of robust 
medRxiv preprint doi: https://doi.org/10.1101/2021.04.10.21255251; this version posted April 17, 2021. The copyright holder for this preprint

(which was not certified by peer review) is the author/funder, who has granted medRxiv a license to display the preprint in perpetuity.

It is made available under a CC-BY-ND 4.0 International license .

phylogenies and the quantification of intra-host genomic diversity of viral samples. Patterns $\mathbf{2}$, $100212(2021)$.

16. Popa, A. et al. Genomic epidemiology of superspreading events in Austria reveals mutational dynamics and transmission properties of SARS-CoV-2. Science Translational Medicine 12, (2020).

17. Lythgoe, K. A. et al. SARS-CoV-2 within-host diversity and transmission. Science (2021) doi:10.1126/science.abg0821.

18. Armero, A., Berthet, N. \& Avarre, J.-C. Intra-Host Diversity of SARS-Cov-2 Should Not

Be Neglected: Case of the State of Victoria, Australia. Viruses 13, 133 (2021).

19. $\mathrm{Xu}, \mathrm{Y}$. et al. Dynamics of severe acute respiratory syndrome coronavirus 2 genome variants in the feces during convalescence. Journal of Genetics and Genomics 47, 610-617 (2020).

20. Pfefferle, S. et al. SARS Coronavirus-2 variant tracing within the first Coronavirus

Disease 19 clusters in northern Germany. Clinical Microbiology and Infection 27, 130.e5130.e8 (2021).

21. James, S. E. et al. High Resolution analysis of Transmission Dynamics of Sars-Cov-2 in Two Major Hospital Outbreaks in South Africa Leveraging Intrahost Diversity. medRxiv 2020.11.15.20231993 (2020) doi:10.1101/2020.11.15.20231993.

22. Shen, Z. et al. Genomic Diversity of Severe Acute Respiratory Syndrome-Coronavirus 2 in Patients With Coronavirus Disease 2019. Clin Infect Dis 71, 713-720 (2020).

23. Wang, D. et al. Population Bottlenecks and Intra-host Evolution During Human-toHuman Transmission of SARS-CoV-2. Front. Med. 8, (2021).

24. Goyal, A., Reeves, D. \& Schiffer, J. T. Early super-spreader events are a likely determinant of novel SARS-CoV-2 variant predominance. medRxiv 2021.03.23.21254185 (2021) doi:10.1101/2021.03.23.21254185.

25. Wölfel, R. et al. Virological assessment of hospitalized patients with COVID-2019. 
medRxiv preprint doi: https://doi.org/10.1101/2021.04.10.21255251; this version posted April 17, 2021. The copyright holder for this preprint

(which was not certified by peer review) is the author/funder, who has granted medRxiv a license to display the preprint in perpetuity.

It is made available under a CC-BY-ND 4.0 International license .

Nature 581, 465-469 (2020).

26. Focosi, D. \& Maggi, F. Neutralising antibody escape of SARS-CoV-2 spike protein: Risk assessment for antibody-based Covid-19 therapeutics and vaccines. Rev Med Virol (2021) doi:10.1002/rmv.2231.

27. Grint, D. J. et al. Case fatality risk of the SARS-CoV-2 variant of concern B.1.1.7 in England, 16 November to 5 February. Euro Surveill 26, (2021).

28. Grabowski, F., Preibisch, G., Giziński, S., Kochańczyk, M. \& Lipniacki, T. SARS-CoV-2 Variant of Concern 202012/01 Has about Twofold Replicative Advantage and Acquires Concerning Mutations. Viruses 13, (2021).

29. Cele, S. et al. Escape of SARS-CoV-2 501Y.V2 from neutralization by convalescent plasma. Nature (2021) doi:10.1038/s41586-021-03471-w.

30. Wang, P. et al. Antibody Resistance of SARS-CoV-2 Variants B.1.351 and B.1.1.7. bioRxiv 2021.01.25.428137 (2021) doi:10.1101/2021.01.25.428137.

31. Widera, M. et al. Bamlanivimab does not neutralize two SARS-CoV-2 variants carrying E484K in vitro. medRxiv 2021.02.24.21252372 (2021) doi:10.1101/2021.02.24.21252372.

32. Shen, X. et al. Neutralization of SARS-CoV-2 Variants B.1.429 and B.1.351. New England Journal of Medicine 0, null (2021).

33. Garcia-Beltran, W. F. et al. Multiple SARS-CoV-2 variants escape neutralization by vaccine-induced humoral immunity. medRxiv 2021.02.14.21251704 (2021) doi:10.1101/2021.02.14.21251704.

34. Madhi, S. A. et al. Efficacy of the ChAdOx1 nCoV-19 Covid-19 Vaccine against the B.1.351 Variant. New England Journal of Medicine 0, null (2021).

35. Kissler, S. M. et al. Densely sampled viral trajectories suggest longer duration of acute infection with B.1.1.7 variant relative to non-B.1.1.7 SARS-CoV-2. medRxiv 2021.02.16.21251535 (2021) doi:10.1101/2021.02.16.21251535.

36. CDC. COVID-19 and Your Health. Centers for Disease Control and Prevention 
medRxiv preprint doi: https://doi.org/10.1101/2021.04.10.21255251; this version posted April 17, 2021. The copyright holder for this preprint

(which was not certified by peer review) is the author/funder, who has granted medRxiv a license to display the preprint in perpetuity.

It is made available under a CC-BY-ND 4.0 International license .

https://www.cdc.gov/coronavirus/2019-ncov/if-you-are-sick/end-home-isolation.html (2020).

37. La Scola, B. et al. Viral RNA load as determined by cell culture as a management tool for discharge of SARS-CoV-2 patients from infectious disease wards. Eur J Clin Microbiol Infect Dis 1-3 (2020) doi:10.1007/s10096-020-03913-9.

38. Rhee, C., Kanjilal, S., Baker, M. \& Klompas, M. Duration of Severe Acute Respiratory Syndrome Coronavirus 2 (SARS-CoV-2) Infectivity: When Is It Safe to Discontinue Isolation? Clinical Infectious Diseases (2020) doi:10.1093/cid/ciaa1249.

39. Rodríguez-Grande, C. et al. Inference of Active Viral Replication in Cases with Sustained Positive Reverse Transcription-PCR Results for SARS-CoV-2. Journal of Clinical Microbiology 59, (2021).

40. Dimcheff, D. E. et al. SARS-CoV-2 Total and Subgenomic RNA Viral Load in Hospitalized Patients. medRxiv 2021.02.25.21252493 (2021)

doi:10.1101/2021.02.25.21252493.

41. Lavine, J. S., Bjornstad, O. N. \& Antia, R. Immunological characteristics govern the transition of COVID-19 to endemicity. Science $371,741-745$ (2021).

42. Herbeck, J. T. et al. Is the virulence of HIV changing? A meta-analysis of trends in prognostic markers of HIV disease progression and transmission. AIDS 26, 193-205 (2012).

43. Watanabe, T. \& Kawaoka, Y. Pathogenesis of the 1918 Pandemic Influenza Virus. PLoS Pathog 7, (2011).

44. Marshall, I. D. \& Fenner, F. Studies in the epidemiology of infectious myxomatosis of rabbits. V. Changes in the innate resistance of Australian wild rabbits exposed to myxomatosis. J Hyg (Lond) 56, 288-302 (1958).

45. Kerr, P. J. et al. Next step in the ongoing arms race between myxoma virus and wild rabbits in Australia is a novel disease phenotype. PNAS (2017) doi:10.1073/pnas.1710336114.

46. Best, S. M. \& Kerr, P. J. Coevolution of host and virus: the pathogenesis of virulent and 
medRxiv preprint doi: https://doi.org/10.1101/2021.04.10.21255251; this version posted April 17, 2021. The copyright holder for this preprint

(which was not certified by peer review) is the author/funder, who has granted medRxiv a license to display the preprint in perpetuity.

It is made available under a CC-BY-ND 4.0 International license .

attenuated strains of myxoma virus in resistant and susceptible European rabbits. Virology 267, 36-48 (2000).

47. Karlin, S. A First Course in Stochastic Processes. (Academic Press, 1966).

48. Li, Q. et al. Prolonged shedding of severe acute respiratory syndrome coronavirus 2 in patients with COVID-19. Emerging Microbes \& Infections 9, 2571-2577 (2020).

49. Bar-On, Y. M., Flamholz, A., Phillips, R. \& Milo, R. SARS-CoV-2 (COVID-19) by the numbers. eLife $\mathbf{9}$,.

50. Plante, J. A. et al. Spike mutation D614G alters SARS-CoV-2 fitness. Nature 592, 116$121(2021)$

51. US Food and Drug Administration. Fact Sheet For Health Care Providers Emergency Use Authorization (EUA) Of Bamlanivimab. 26.

52. de Souza, W. M. et al. Levels of SARS-CoV-2 Lineage P.1 Neutralization by Antibodies Elicited after Natural Infection and Vaccination. SSRN Journal (2021) doi:10.2139/ssrn.3793486.

53. CDC. Science Brief: Emerging SARS-CoV-2 Variants. Centers for Disease Control and Prevention https://www.cdc.gov/coronavirus/2019-ncov/science/science-briefs/scientific-briefemerging-variants.html (2020).

54. PANGO lineages. https://cov-lineages.org/global_report.html.

55. Another new coronavirus variant found in Japan | The Japan Times.

https://www.japantimes.co.jp/news/2021/01/11/national/science-health/new-coronavirusvariant-japan/.

56. CDC. SARS-CoV-2 Variant Classifications and Definitions. Centers for Disease Control and Prevention https://www.cdc.gov/coronavirus/2019-ncov/cases-updates/variantsurveillance/variant-info.html (2020). 


\section{ACKNOWLEDGEMENTS}

None.

\section{AUTHOR CONTRIBUTIONS}

DVE, MS, and AC conceived the original study design. DVE and AC designed the mathematical modeling approach and wrote the first draft. DVE conducted the modeling, with input from MS and AC. AN and UT contributed text to the Introduction, Discussion and Supplemental Materials. All authors edited and provided input into the manuscript.

\section{ADDITIONAL INFORMATION}

Funding statement: A.N. acknowledges funding from the National Science Foundation Graduate Research Fellowship Program under Grant No. DGE-1762114. Any opinions, findings, and conclusions or recommendations expressed in this material are those of the author(s) and do not necessarily reflect the views of the National Science Foundation. Fractal Therapeutics provided support in the form of salaries for authors M.S. and U.T., but did not have any additional role in the study design, data collection and analysis, decision to publish, or preparation of the manuscript. The specific roles of these authors are articulated in the 'author contributions' section.

Competing interest statement: A.C., M.S., and U.T. are employees and shareholders of Fractal Therapeutics. D.V.E., A.N., and D.J.-M. are shareholders of Fractal Therapeutics. This does not alter our adherence to journal policies on sharing data and materials. 


\section{FIGURES AND FIGURE LEGENDS}

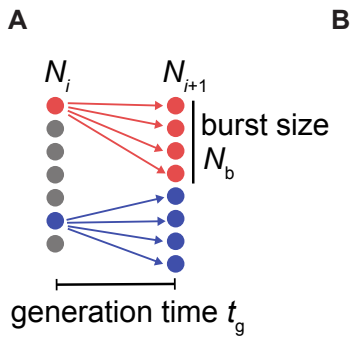

D

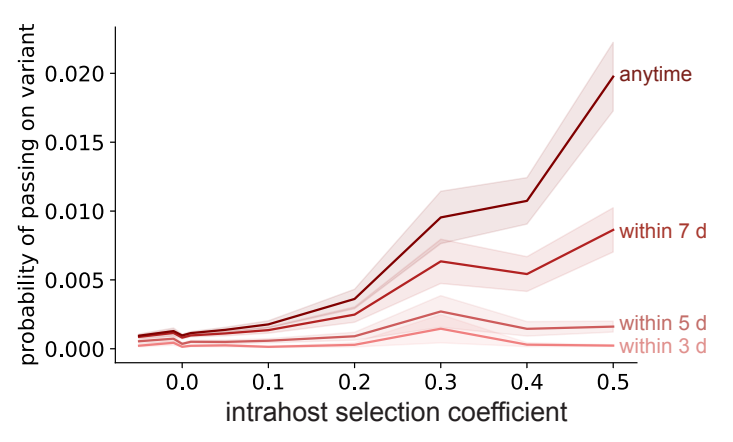

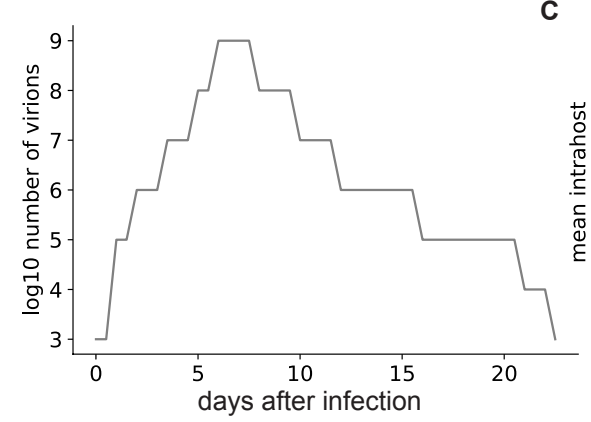

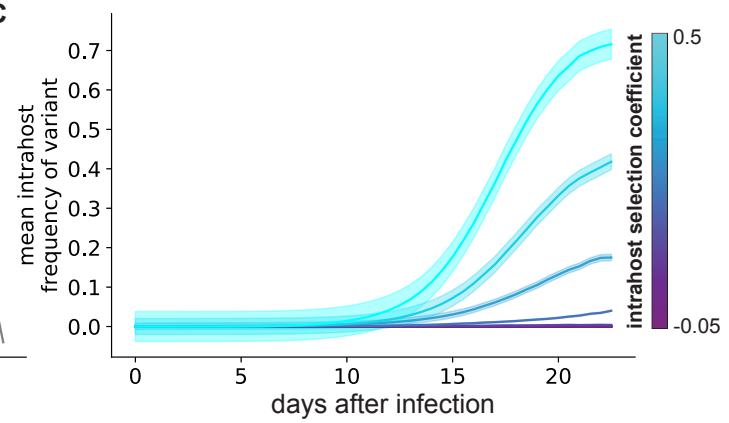

E

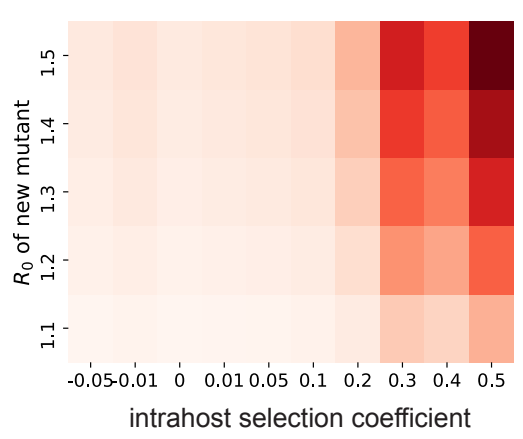

Figure 1. Selection within individuals with COVID-19 leads to selection of more fit viral variants. A. Schematic of viral replication model used to simulate SARS-CoV-2 evolutionary dynamics. B. Sputum viral load curve for a typical COVID-19 infection. The x-axis represents the time starting from the initial transmission event that started the infection. C. Mean frequency of variants with point mutations within individuals with COVID-19 for different mutation fitness effects (colors). D. Probability of a specific single mutation to be present in at least one virion transmitted if transmission occurs within the first 3-7 days of infection (lighter red curves) or anytime during infection (darker red). For $\mathbf{C}$ and $\mathbf{D}$, shaded areas represent \pm SEM, $n=1000$ simulations per condition. E. Number of total new single mutant infections generated per day that establish a surviving variant lineage, assuming all infections are of standard length with viral load profile given in $\mathbf{B}$ and that transmission occurs within the first 7 days of infection. Unless otherwise specified, simulation parameter values are those given in Table 1. 

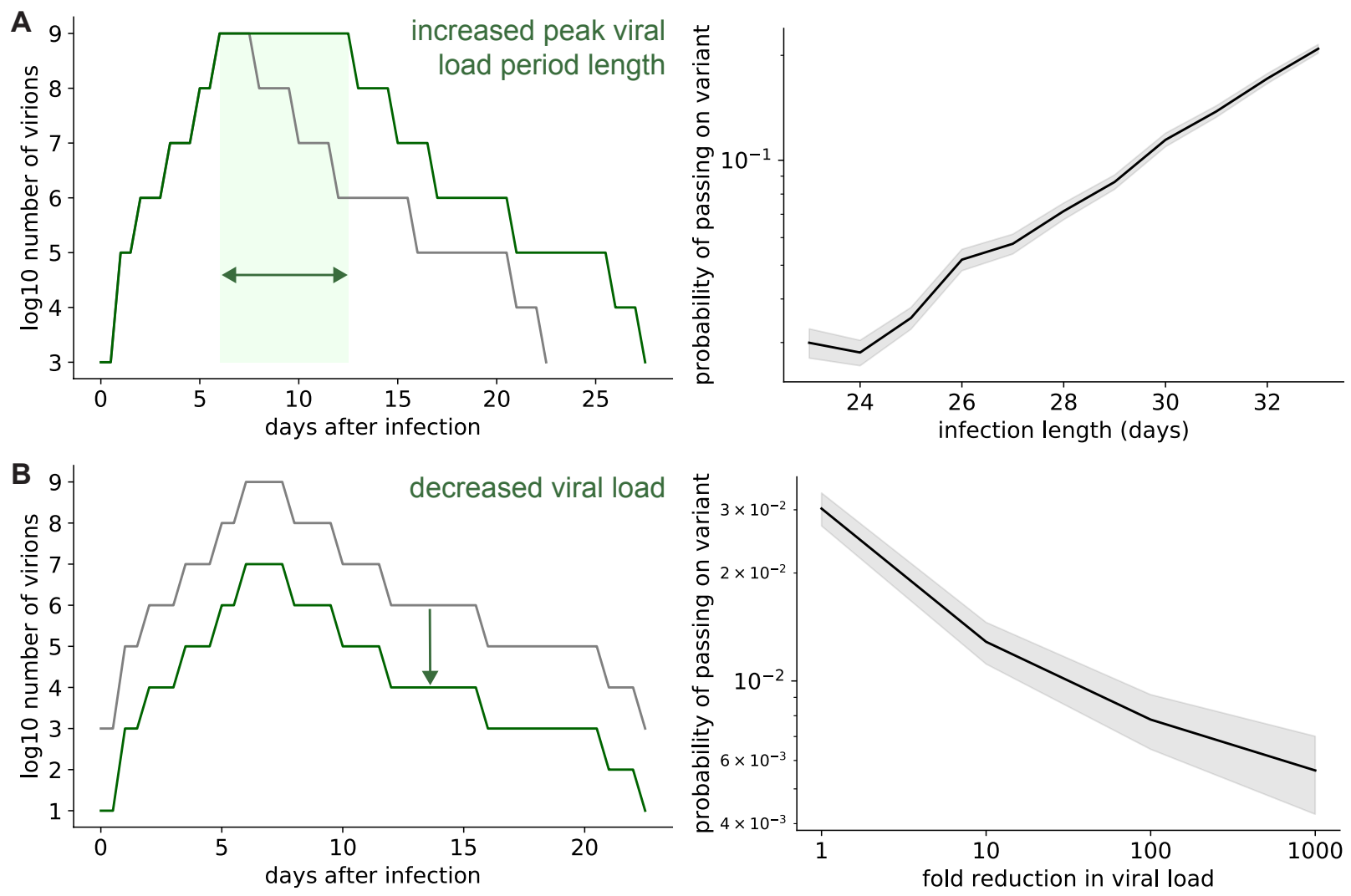

Figure 2. Within-host selection is stronger for infections that last longer or have higher viral loads. A. Probability that at least one transmitted virion has a specific advantageous single mutation, for different overall lengths of infection. Infection lengths were adjusted by increasing the length of the peak viral load period (left panel schematic). B. Probability that at least one transmitted virion has a specific single mutation, for different viral loads. Viral loads were adjusted by reducing the viral load by a constant factor over the entire course of infection (left panel schematic). For right panels, shaded areas represent \pm SEM, $n=1000$ simulations per condition, with a selection coefficient of 0.2 for the single mutant. Unless otherwise specified, simulation parameter values are those given in Table 1. 
A

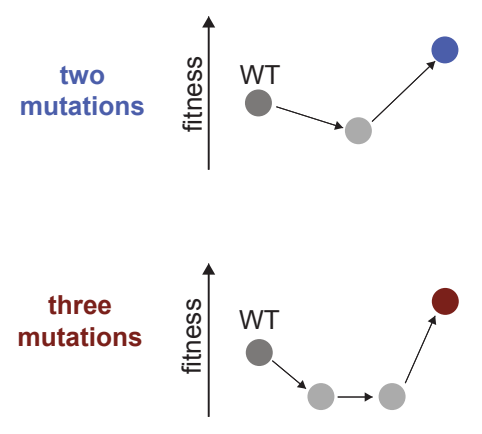

C

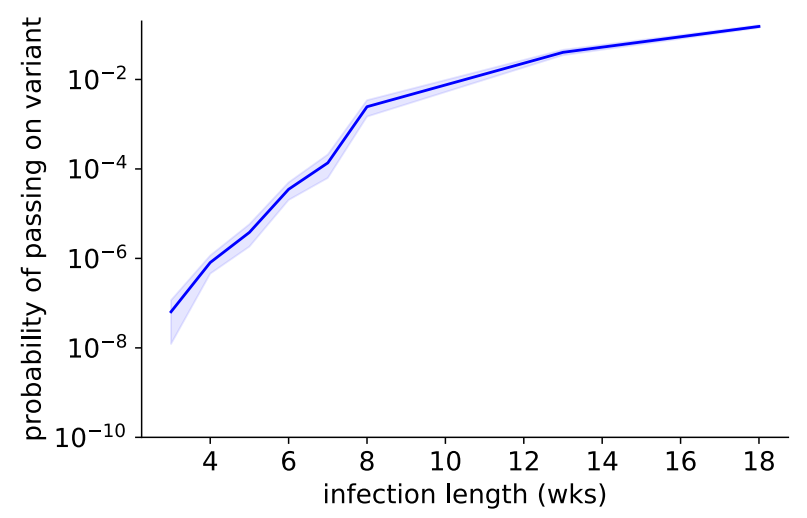

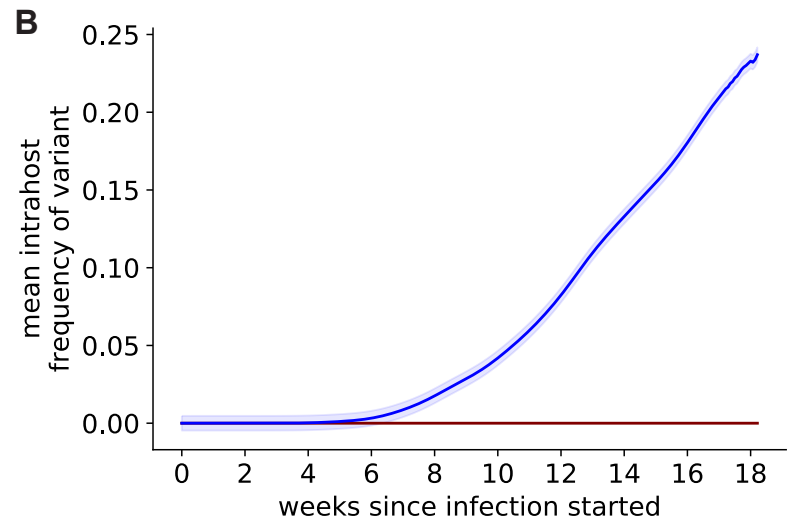

D

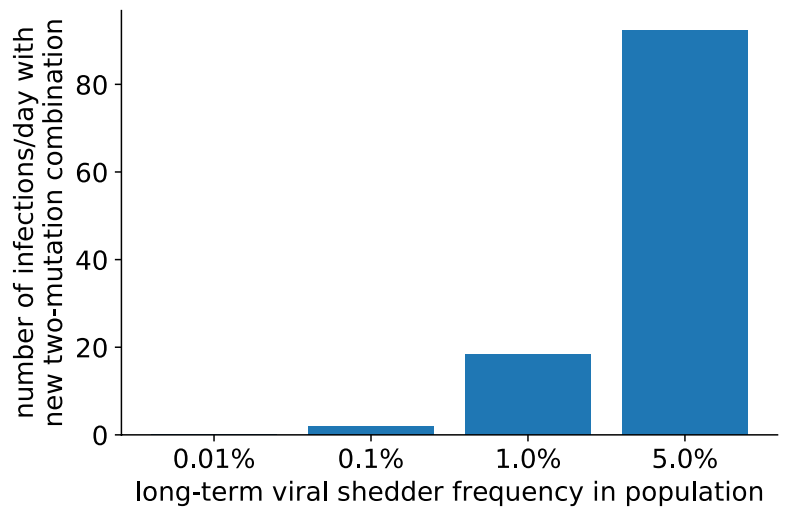

Figure 3. SARS-CoV-2 can acquire multiple mutations during infections with sustained viral replication. A. Fitness valley crossing model for acquisition of multiple mutations. Intermediate states with fewer mutations (light grey) have lower fitness than the WT virus within individuals, while variants with a specific combination of two or three mutations (blue and red, respectively) have higher fitness. B. Mean frequency of variants with a beneficial combination of two (blue) or three (red) mutations within individuals with long-term SARS-CoV-2 infection. C. Probability of a beneficial combination of two mutations (blue line) to be present in at least one virion transmitted if transmission occurs anytime during infection. For $\mathbf{B}$ and $\mathbf{C}$, shaded areas represent \pm SEM, $n=1000$ simulations per condition. D. Number of de novo double mutant infections that establish a surviving lineage when some COVID-19 patients shed live virus for more than 30 days after developing symptoms. Deleterious intermediates had a fitness cost of 0.05 and beneficial mutation combinations had a selective advantage of 0.2 . Unless otherwise specified, simulation parameter values are those given in Table 1. 
medRxiv preprint doi: https://doi.org/10.1101/2021.04.10.21255251; this version posted April 17, 2021. The copyright holder for this preprint (which was not certified by peer review) is the author/funder, who has granted medRxiv a license to display the preprint in perpetuity.

It is made available under a CC-BY-ND 4.0 International license .

A

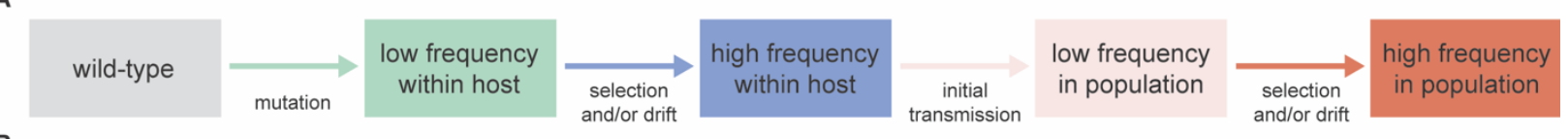

B

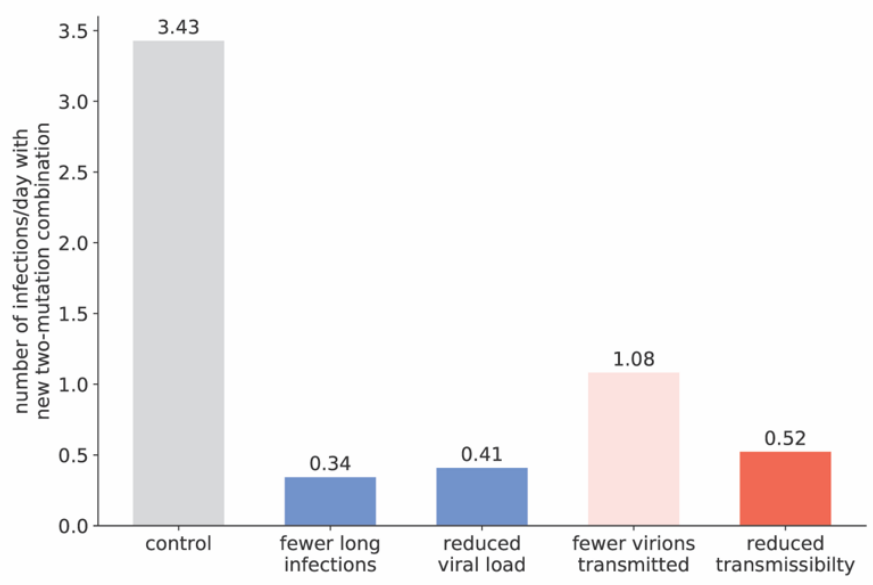

Figure 4. Interventions targeting stochastic events during infection or transmission reduce the efficiency of SARS-CoV-2 evolution. A. Schematic showing events necessary for the generation and population-level establishment of a new SARS-CoV-2 variant. B. Reduction in generation rate of new double mutant lineages that establish in the entire population caused by interventions targeting different events required to create a new surviving viral variant $(n=1000$ simulations per condition). Each intervention reduces the stated parameter value by $90 \%$. Parameter value changes are relative to the control parameter set given in Table 1 , with $0.1 \%$ of new infections lasting $>30$ days after symptom onset. The "reduced transmissibility" condition refers to a $90 \%$ reduction in the transmission advantage of the variant, leading to an $R_{0}$ of 1.05 . 


\section{TABLES}

Table 1. Parameter values used for intrahost SARS-CoV-2 evolutionary dynamics simulations.

\begin{tabular}{|c|c|c|c|}
\hline Name & Description & Value & Source \\
\hline$t_{\mathrm{g}}$ & SARS-CoV-2 replication cycle length & 12 hours & 49 \\
\hline$N_{\mathrm{b}}$ & $\begin{array}{l}\text { Viral burst size- number of virions produced } \\
\text { by each infected cell }\end{array}$ & 1000 & 49 \\
\hline$\mu$ & $\begin{array}{l}\text { Within-host SARS-CoV-2 mutation rate (per } \\
\text { replication cycle, per site) }\end{array}$ & $10^{-5}$ & 49 \\
\hline$N_{\text {trans }}$ & Number of virions transmitted to new host & 10 & 17 \\
\hline$R_{0}$ & $\begin{array}{l}\text { Reproductive number- average number of } \\
\text { new hosts infected by a single infected host }\end{array}$ & 1.5 & $\begin{array}{l}\text { Similar to the } \\
\text { transmission } \\
\text { advantage } \\
\text { measured for } \\
\text { B.1.1.75 }\end{array}$ \\
\hline$\sigma$ & Number of new infected hosts (per day) & 50,000 & $\begin{array}{l}\text { Similar to recently } \\
\text { reported numbers } \\
\text { for the US }\end{array}$ \\
\hline$L_{L T}$ & $\begin{array}{l}\text { Mean ( } \pm \text { standard deviation) of infection } \\
\text { length in long-term SARS-CoV-2 shedders }\end{array}$ & $\begin{array}{l}93.75 \text { days } \pm \\
11.48\end{array}$ & 48 \\
\hline
\end{tabular}


medRxiv preprint doi: https://doi.org/10.1101/2021.04.10.21255251; this version posted April 17, 2021. The copyright holder for this preprint

(which was not certified by peer review) is the author/funder, who has granted medRxiv a license to display the preprint in perpetuity.

It is made available under a CC-BY-ND 4.0 International license.

\section{SUPPLEMENTAL MATERIAL}

\section{Notes on phenotypic changes conferring fitness advantages in SARS-CoV-2 variants}

Several variants with phenotypic changes have been characterized. Increased transmissibility (which has been observed in vivo with spike protein mutations such as $\mathrm{D} 614 \mathrm{G}^{50}$ ) best explains the rapid spread of B.1.1.7 in multiple countries ${ }^{5}$. Greater lethality has been observed for the B.1.1.7 variant ${ }^{27}$ along with faster replication (e.g. B.1.1.7) ${ }^{28}$. Increased potential for reinfection is seen for B. $1.351^{29}$. Multiple variants evade antibody therapies: for instance B.1.526, B.1.429, B.1.427, P.1 and B.1.351 are all resistant to spike-targeting monoclonal antibody bamlanivimab ${ }^{51}$. In other cases, reduced susceptibility to vaccines has been reported. In the extreme case, the variant B.1351 wholly evades the ChAdOx1 vaccine ${ }^{34}$. In vitro work found that sera from people vaccinated with CoronaVac does not neutralize the P.1 variant ${ }^{52}$. This explains the reported lower efficacy of CoronaVac in clinical trials in Brazil, where P.1 is prevalent, when compared to the United Arab Emirates. In vivo data, such as sequencing of breakthrough infections, would strengthen or falsify this hypothesis. Some viral variants have also been associated with longer duration of infection ${ }^{35}$, which is particularly concerning in the light of the findings in this report.

This list is not comprehensive, and new data are constantly being reported. 
medRxiv preprint doi: https://doi.org/10.1101/2021.04.10.21255251; this version posted April 17, 2021. The copyright holder for this preprint (which was not certified by peer review) is the author/funder, who has granted medRxiv a license to display the preprint in perpetuity.

It is made available under a CC-BY-ND 4.0 International license .

\section{Supplementary Table S1. Emergence of currently common SARS-CoV-2 variants}

\begin{tabular}{|l|l|l|l|}
\hline Variant & $\begin{array}{l}\text { Site of } \\
\text { Emergence }\end{array}$ & $\begin{array}{l}\text { Date first } \\
\text { reported }\end{array}$ & $\begin{array}{l}\text { Local case frequency since } \\
\text { emergence as of 4/4/2021 }\end{array}$ \\
\hline B.1.351 & South Africa & October $2020^{53}$ & $1668 / 2301(72.5 \%)^{54}$ \\
\hline B.1.1.7 & UK & September $2020^{53}$ & $173624 / 277811(62.5 \%)^{54}$ \\
\hline P.1 & Brazil & January $2021^{55}$ & $584 / 1519(38.4 \%)^{54}$ \\
\hline
\end{tabular}

The B.1.351 variant was first identified in South Africa and quickly became the dominant variant in South Africa and in many other countries. As of April 4th 2021, the B.1.351 variant accounted for $72.5 \%$ of the case frequency in Brazil, and 7 other countries have at least a $72 \%$ frequency of B.1.351. This variant is known to increase the transmission rate and moderately impact neutralization by monoclonal antibodies ${ }^{56}$.

The B.1.1.7 variant first emerged in the UK in December 2020. By late December 2020 (week 52 of 2020), B.1.1.7 became the dominant variant, with a frequency of $51.31 \%$. This variant is known to increase transmissibility and may increase risk of death compared with other variants $^{5,27}$

There are also some shared mutations among these three variants. The P.1. variant and B.1.351 variant share three mutations in the Spike protein, while the P.1. variant and B.1.1.7 share the N501Y mutation ${ }^{56}$. 